\section{AROUND THE WORLD}

The tooth fairies' jurisdiction is extensive. However, they do have some colleagues and tricks to share the load of primary teeth collection around the world:

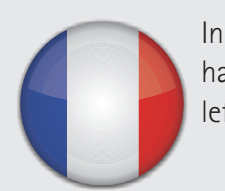

In France 'la petite souris' (or little mouse) has responsibility for taking baby teeth left under the pillows of sleeping children.

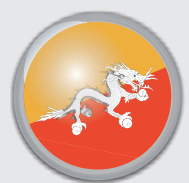

The tradition in Bhutan is to have the child throw their lost tooth onto the roof of their house as an offering to the moon goddess. She is supposed to grant them strong, healthy, new teeth.

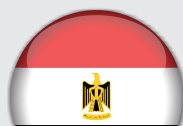

In Egypt the milk tooth is wrapped in a cloth and thrown as high as possible to Ra (the sun god) while reciting, 'Shiny sun, shiny sun, take this buffalo's tooth and bring me a bride's tooth'

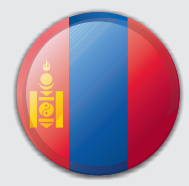

In Mongolia children roll their lost primary teeth in meat fat and feed them to their dogs. They do this in the hope that their adult teeth will be as strong as those of the bone-eating dog. When children don't have dogs, they bury their baby teeth in the ground near a big tree so that their new teeth will have strong roots just like the tree.

In Swaziland children put the teeth in their shoes overnight in the hope that they will find some sweets there in the morning.

In Spain, a rat called Ratoncito Pérez comes to visit children at night when they lose their primary teeth. Pérez, from Madrid, is said to live in a box of sugar cookies with his wife, La Ratita Presumida (vain little mouse), and his children. When he hears the sound of a child's falling tooth, he kisses his beautiful wife goodbye and scurries through the maze of pipes underneath Madrid to the child's bedroom. In exchange for the tooth, it is customary that he will also leave a gift, usually one of the cookies from his own home.

\section{FROM THE ARCHIVE}

7 he news story below was published in the BDJ in February 1991. Stephen Hancocks OBE, the BDJ's current Editor-in-Chief, was first published in the $B D J$ as a freelance at the invitation of Margaret Seward, former Editor, around 1984. Dr Hancocks then covered several meetings and wrote a series on 'badges of the dental profession' which were used as fillers from time to time. He was employed to work two days a week specifically on the $B D J$ as the commissioning editor in 1996 and became Editor-in-Chief in 2004.

\section{NEW EDITORIAL AND PUBLISHING POST}

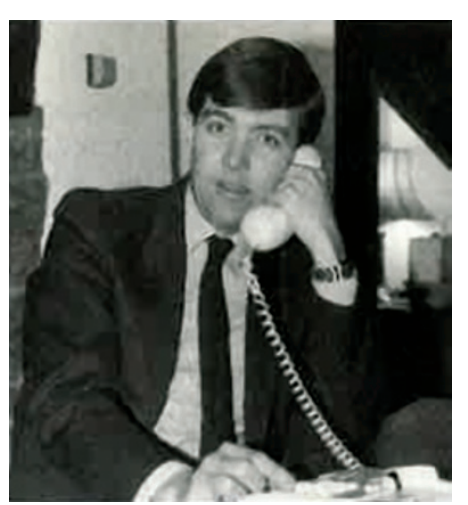

Stephen Hancocks will now be working full time at 64 Wimpole Street appointed to a unique position in which he will be writing and editing for both the BDA and the FDI.

As deputy editor of BDA News, Stephen will be increasing his time from one to 2 days per week. This will enable him to help the News develop in the ways in which recent surveys of members and readers have indicated.

The FDI is also in the process of reorganising and redesigning its publications as both short and long term projects. Stephen's main, immediate task here will be establishing the feasibility of publishing a new World Dental Journal. The appointment consolidates a long association with the FDI, for whom he first started writing in 1982 after answering an advert in the $B D J$ which posed the question, 'Are you a keen writer?'

Asked if he would miss clinical dentistry Stephen, who will keep a connection with previous employers, West Essex Health Authority, as honorary senior dental officer, said that he thought not, as getting to grips with the new jobs would occupy him thoroughly.

'Although I have been a freelancer writer for some years I don't think I ever really imagined that I would get the opportunity to make my livelihood from it,' he said. 'Being offered this unique position was something I just couldn't turn down. It is immensely exciting.'

Although working 3 days a week for the FDI and 2 for the BDA, Stephen will be 'available' to each organisation throughout the week. This arrangement provides the maximum flexibility and solves the problems of being only 'BDA' or 'FDI' on particular days. Stephen will be working for both organisations from one office and may be contacted on the phone number of either organisation.

With thanks to Helen Nield, BDA Library Manager.

\section{TRICLOSAN COULD BOOST FLUORIDE BENEFITS IN TOOTHPASTES}

A review prepared by the Cochrane Oral Health Group suggests that fluoride toothpastes containing antibacterial agent triclosan, and copolymer, which aids retention of the agent during rinsing, boosts reduction in plaque, caries, gingival inflammation and bleeding. ${ }^{1}$
Analysis of 14,835 participants across 30 studies found that after six months of using triclosan/copolymer fluoride toothpaste there was a $22 \%$ reduction in plaque and gingivitis, a $48 \%$ reduction in bleeding gums and a 5\% reduction in caries. Triclosan fights bacteria in plaque and reduce swelling of the gums.

Further reviews are needed to assess the clinical importance of these results compared to fluoride toothpastes that do not contain triclosan, and fluoride toothpastes that contain other antibacterial agents.

Preventable caries and gum disease place a great burden on healthcare so this could be a low-cost answer to the problem.

1. Riley P, Lamont T. Triclosan/copolymer containing toothpastes for oral health. Cochrane Database Syst Rev 2013; CD010514 